\title{
Identification and Ceramic Application of Some Tunisian Clays
}

\author{
Salah Mahmoudi' ${ }^{1}$ Ezzeddine Srasra ${ }^{2}$, Fouad Zargouni ${ }^{3}$ \\ ${ }^{1}$ Department of Earth Sciences, Faculty of Sciences of Gabes, Gabes, Tunisia \\ ${ }^{2}$ Materials Center, Technopolis of Borj Cedria, Hammam Lif, Tunisia \\ ${ }^{3}$ Department of Geology, Faculty of Sciences of Tunis, Tunis, Tunisia \\ Email: salahmahmoudii@yahoo.fr
}

Received 8 January 2015; accepted 25 January 2015; published 28 January 2015

Copyright (C) 2015 by authors and OALib.

This work is licensed under the Creative Commons Attribution International License (CC BY). http://creativecommons.org/licenses/by/4.0/

(c) (i) Open Access

\begin{abstract}
Mineralogy, chemistry, and plasticity of the raw clay materials, outcropping in different Tunisian domains were studied. These clays constitute the only mineral resource of the ceramic industries in Tunisia, and are exploitable at eight quarries. Powder X-ray diffraction analysis revealed that illite and kaolinite are the major mineral phases. However, other clay minerals, such as illite/ smectite mixed-layer, and chlorite are also present. The associated minerals detected in powdered materials are: quartz, calcite, feldspar and, dolomite. These raw materials are marly clays with $6 \%$ - 14\% CaO, represented essentially by calcite; they show the greatest relative amount of $\mathrm{Na}_{2} \mathrm{O}+$ $\mathrm{K}_{2} \mathrm{O}(\sim 3.5 \%)$ and iron-oxide $(\sim 6 \%)$. The plasticity index and liquid limit of crude samples do not exceed $22 \%$ and $42 \%$, respectively. This indicates that these clays belong to the zone of illitic clays, classified in the low to moderate plastic domain. The analysis will be used to find appropriate applications for traditional ceramic. In addition, this paper shows that the ceramic defects observed in the pieces manufactured from these Tunisian clays are lamination, cracks, and lower mechanical and bending strength. Some solutions are assured to avoid these ceramic defects.
\end{abstract}

\section{Keywords}

Clays, Plasticity, Ceramic Defects, Tunisia

Subject Areas: Geology, Industrial Engineering, Mineral Engineering, Mineralogy

\section{Introduction}

The raw materials used by Tunisian industries of ceramic are Barremian clays of Jebel Oust, Aptian clays of Jebel Ressas, and Triassic clays of Mednine abbreviated BO, AR, and TM, respectively, belonging to various regions of Cretaceous and Triassic formations of Tunisia (Figure 1). The geological data of these clays are 

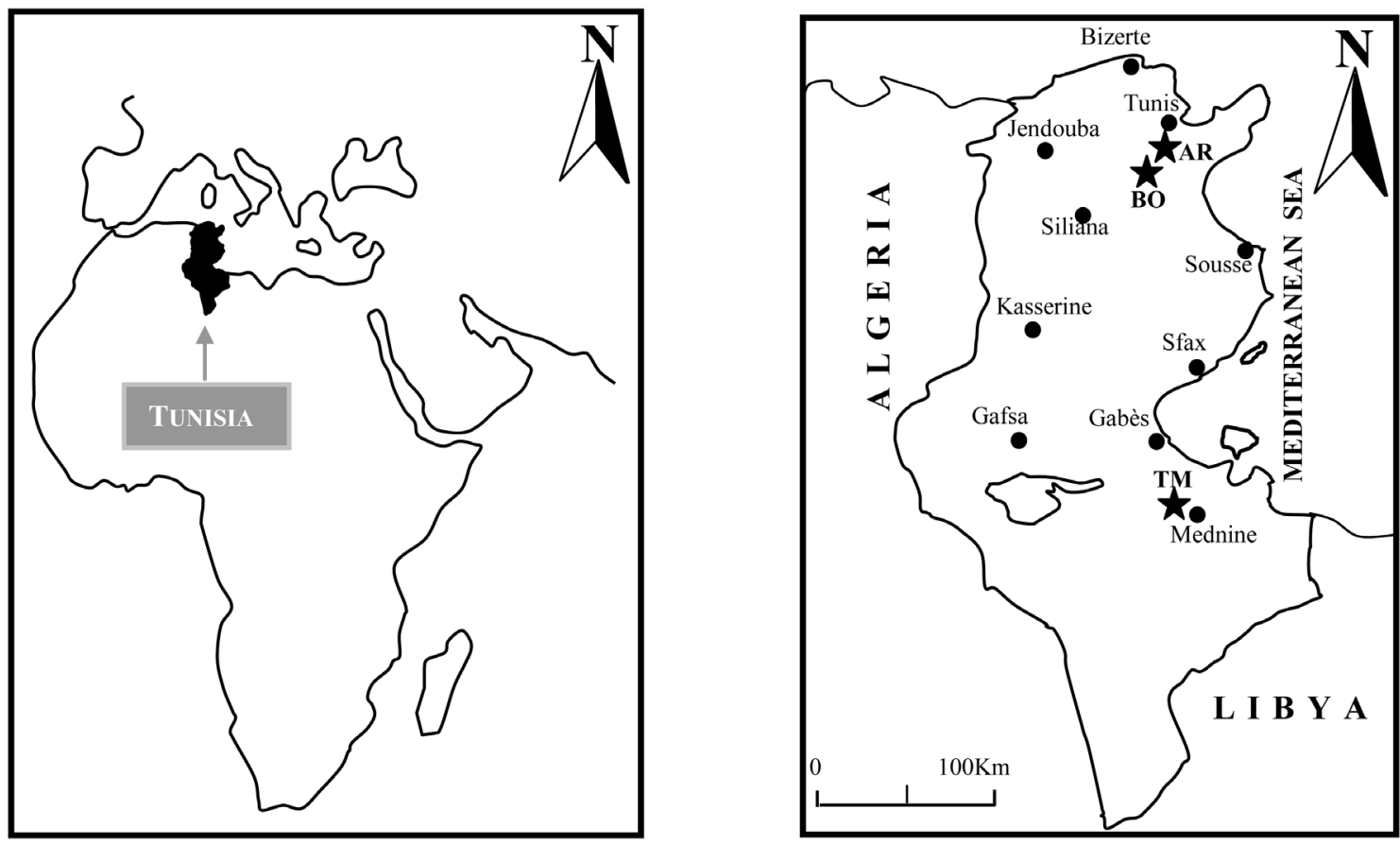

Figure 1. Location map of the samples.

described in several publications [1]-[6]. BO sample was selected from Bir M'cherga formation, outcropped in the flank of an anticline with a core composed of Jurassic rocks. The Barremian argillaceous rocks green-gray to dark gray and contain 1 - 2 m-thick calcareous interbeds (see the geological map of Bir M'Cherga No. 28 at 1/50,000 scale). On the other hand, the study was carried out with AR clay sample from Jebel Ressas (see the geological map of Grombalia No. 29 at 50,000 scale). The studied sector is composed of Jurassic limestones and dolomitic limestones. The Jurassic ground is surrounded by Cretaceous clays. The clay deposits contain an important reserve which comprises alternation of calcareous and sandstone levels. The average thickness of useful clays is $400 \mathrm{~m}$. Concerning TM clay, is a representative sample from Triassic Tejra Sghira quarry. These sedimentary clays are situated at $9 \mathrm{~km}$ north of Mednine city in the southeast Tunisia. The Sidi Stout formation, which is probably lower Triassic in age, is composed of red argillaceous rocks with alternation of sandstone levels. The argillaceous mass contains some gypsum crystals. The thickness of useful clay reaches $500 \mathrm{~m}$.

Traditional ceramic is frequently used in numerous countries in the world. In particular, in Tunisia, several researches have been carried out to identify the application of clays in traditional ceramic [3]-[8]. These studies show that the raw materials are illite-kaolinite-rich or illitic clays, with small linear drying and firing shrinkage. The plasticity test shows low $(\mathrm{PI}=14)$ and medium $(\mathrm{PI}=22)$ values according to the L.C.P.C. [9]. These analyses show that these clays could be used in the manufacturing of ceramic materials.

Jeridi et al. [10] studied lower Cretaceous and Oligocene clays from northern Tunisia were analysed to evaluate their possible use in the production of earthenware tiles by dry processing and fast double-firing. This study specifically discusses two different formulations: M1 $=80 \%$ Barremian clays $+20 \%$ Chamotte and, M2 $=24 \%$ Barremian clays $+50 \%$ Aptian clays $+10 \%$ Oligocene clays $+16 \%$ Chamotte. These mixtures show that the the main defects in glazed bodies were chipping in both formulations and some pinholes and tiny craters in mixture M2, invariably on bright white glaze.

Though the research devoted to the ceramic defects generated significant theoretical developments, it is surprisingly neglected by the academic communities. We are interested in the pieces produced in the ceramic industries using dry process, because these, compared to wet processing present advantages in energy (gas and electricity), capital coats, and water consumption [11]. In this context, our presence in the ceramic industries (dry process) allows us observe some defects. The aim of this research is to characterize the most representative defects of ceramic products observed after pressing, drying, and firing and the possible solutions in the factories using dry process. This work will give a better understanding of the raw materials and ceramic bodies to indus- 
trialists as well as to the investors in Tunisia; consequently, it helps to ameliorate the quality of products.

\section{Materials and Methods}

X-ray powder diffraction diagrams (XRD) were obtained using a Philips X'Pert diffractometer at the Centre of Researches and Technology of Energy (C.R.T.E.). The patterns in unoriented preparations were obtained with $\mathrm{CuK}_{\alpha}$ radiation $(1.5418 \AA$ ), at $40 \mathrm{kV}$ and $40 \mathrm{~mA}$. For the semi-quantitative analysis of the samples, the relative abundance of minerals was estimated from the intensity of the main reflections.

Chemical analyses were obtained by atomic absorption spectroscopy. Loss on ignition (LOI) was measured from total weight after ignition at $1000^{\circ} \mathrm{C}$ for $2 \mathrm{~h}$.

The Atterberg limits (liquid limit (LL), plastic limit (PL), and plastic index (PI), PI = LL-PL) were defined by [12]-[15]. These parameters were determined by the Casagrande method [9] [14], in accordance with the French Standard NF P 94-051.

To prepare specimens, the clays have been dried at $105^{\circ} \mathrm{C}$ for $24 \mathrm{~h}$, dry-ground for $15 \mathrm{~min}$ in a ball mill, sifted through a $1 \mathrm{~mm}$, and humidified at $7 \%$ water content. Ceramic bodies were prepared from mixture $\mathrm{M}=50 \%$ Aptian clays $+20 \%$ Barremian clays $+20 \%$ Triassic clays $+10 \%$ sand. The sand added to mixture $\mathrm{M}$, comes from Sidi Aïch formation, which was well-studied by Gallala et al. [16]. These ceramic specimens were manufactured by pressing technique at the pressure $\left(200-250 \mathrm{~kg} / \mathrm{cm}^{2}\right)$ using $(10 \times 5 \times 1) \mathrm{cm}^{3}$ molds and then dried at $105^{\circ} \mathrm{C}$ for $24 \mathrm{~h}$. The specimens were fired in an electric furnance with $10^{\circ} \mathrm{C} /$ min heating rate at temperature $1100^{\circ} \mathrm{C}$ for $60 \mathrm{~min}$.

\section{Results and Discussion}

\subsection{Materials Characterization}

\subsubsection{XRD Analyses}

The mineralogical compositions of the bulk and the $<2 \mu \mathrm{m}$ fraction are listed in Table 1 and Figure 2. Quartz is the major quantity (reflections at 4.26 and $3.33 \AA$ ) in the AR and TM clays. But calcite (reflection at $3.03 \AA$ ) is the main mineral in the BO sample powder. XRD diagram shows also that the non-clay minerals are feldspar and dolomite, which are present with small quantity. TM clay contains small amounts of gypsum ( 10\%).

The $<2 \mu \mathrm{m}$ fraction indicates the predominance of illite (65\% and $55 \%$ for AR and BO, respectively). In general, the illitic clays are frequency used for ceramic products [17]-[20]. TM is kaolinic-illitic clay, with minor amounts of chlorite ( 10\%) (Table 1$)$.

\subsubsection{Chemical Analyses}

The chemical analyses of the oxide percentages of the studied samples are shown in Table 2. The results expressed in oxide percentages, confirm the presence of silica (50\% - 60\%) from clay minerals, quartz, and feld-

Table 1. The mineralogical analyses of studied clays.

\begin{tabular}{ccccc}
\hline \multicolumn{2}{c}{ Mineralogy (\%) } & Sample AR & Sample BO & Sample TM \\
\hline & Clay minerals & 50 & 50 & 45 \\
& Quartz & 25 & 15 & 30 \\
Whole rock sample (\%) & Calcite & 17 & 25 & 05 \\
& Feldspar & 08 & 10 & 00 \\
& Dolomite & 00 & 00 & 10 \\
& Gypsum & 00 & 00 & 10 \\
\hline \multirow{3}{*}{$<\mathbf{\mu m}$ fraction } & Illite & 65 & 55 & 40 \\
& Illite/Smectite & 20 & 20 & 00 \\
& Kaolinite & 15 & 15 & 50 \\
& Chlorite & 00 & 10 & 10 \\
\hline
\end{tabular}




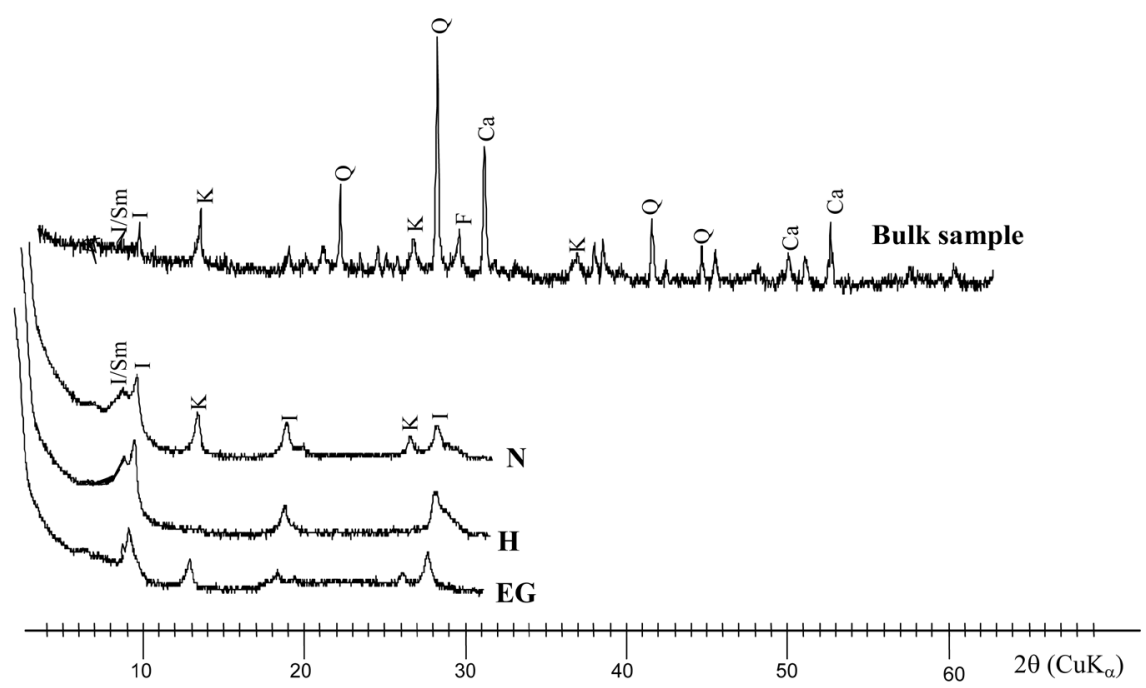

(a)

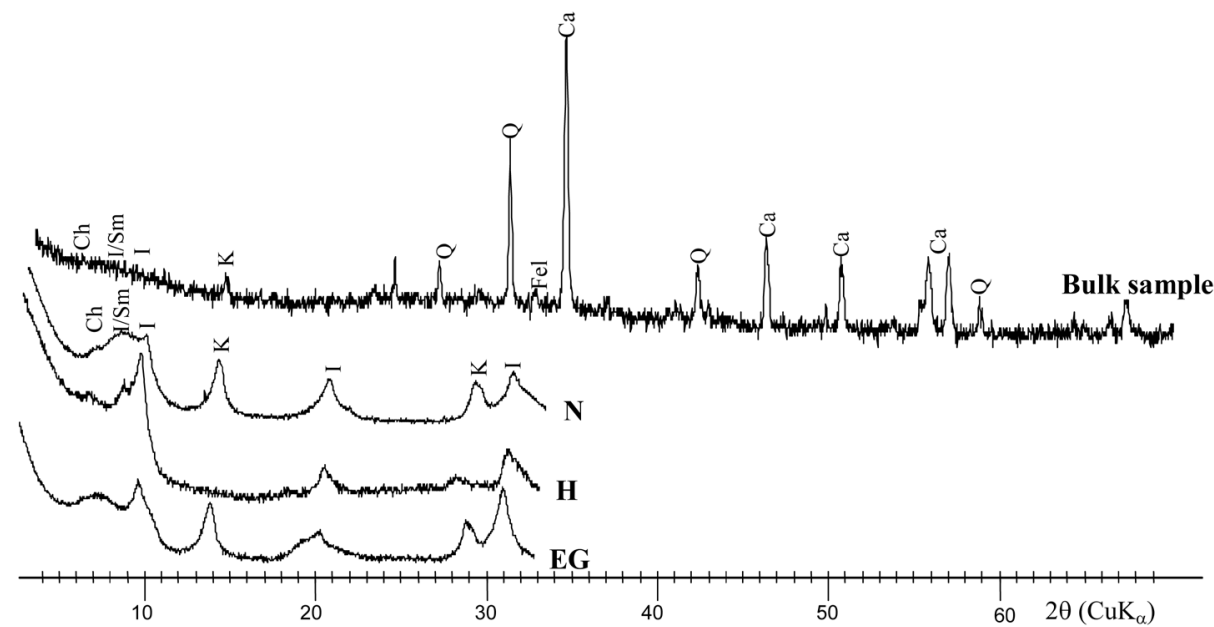

(b)

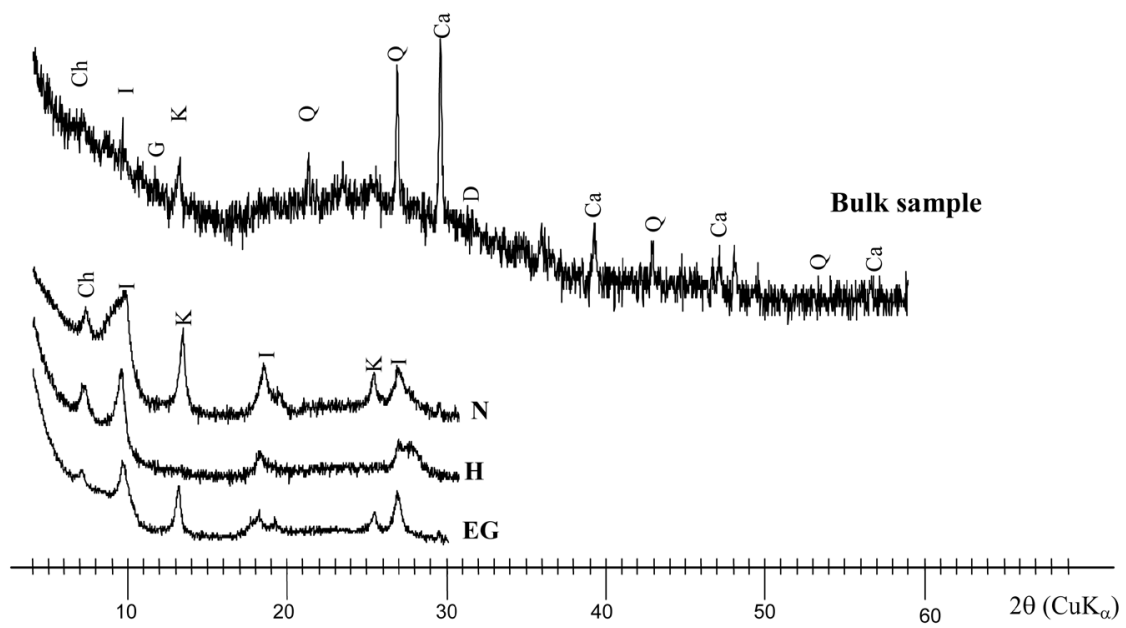

(c)

Figure 2. Powder XRD patterns of bulk and clay fraction of samples AR (a), BO (b), and TM (c); N: oriented aggregate; EG: saturated with ethylene glycol; H: heated at $550^{\circ} \mathrm{C}$; Q: quartz; Ca: calcite; F: feldspars; D: dolomite; G: gypsum; I: illite; K: kaolinite, and I/Sm: interstratified illite/smectite. 
Table 2. The chemical analyses of studied clays.

\begin{tabular}{cccc}
\hline Elements oxide \% & Sample AR & Sample BO & Sample TM \\
\hline $\mathrm{SiO}_{2}$ & 51.57 & 49.02 & 58.51 \\
$\mathbf{A l}_{2} \mathbf{O}_{3}$ & 19.01 & 15.25 & 17.48 \\
$\mathbf{F e}_{2} \mathbf{O}_{3}$ & 7.52 & 4.34 & 6.37 \\
$\mathbf{C a O}$ & 6.33 & 13.38 & 3.21 \\
$\mathbf{M g O}$ & 1.97 & 1.54 & 2.67 \\
$\mathbf{N a}_{2} \mathbf{O}$ & 0.67 & 0.62 & 0.41 \\
$\mathbf{K}_{2} \mathbf{O}$ & 3.35 & 2.52 & 3.38 \\
$\mathbf{T i O}$ & 0.34 & 0.27 & 0.24 \\
$\mathbf{M n O}$ & 0.24 & 0.44 & 0.11 \\
$\mathbf{L O I}$ & 8.52 & 11.67 & 7.27 \\
\hline
\end{tabular}

spar. The alumina (15\% - 20\%) comes from clay minerals and feldspar; in and the alkaline elements, mainly potassium oxide associated with illite content for all samples. The alkalis content $\left(\mathrm{K}_{2} \mathrm{O}+\mathrm{Na}_{2} \mathrm{O}\right)$ is high $(\sim 3.5 \%)$. These oxides reduce the refractory temperature of clays [21]. The iron oxide content varies between $4 \%$ and $8 \%$ and it can be considered acceptable which is in agreement with the range used in the literature for ceramic production. This oxide will reflect a uniformity and stability of the tonality of color after firing [22] [23].

The chemical and mineralogical analyses of the studied samples are in coincidence with the clays used as ceramic raw materials reported in the literature [24]-[27].

\subsubsection{Plasticity}

The parameters of plasticity are listed in Table 3 and Figure 3 show the position of these clays on the Holtz and Kovacs Diagram [28]. AR clay falls in the category of illitic clays and could be considered as moderately plastic. $\mathrm{BO}$ and TM clays also exist in the zone of illitic clays (Figure 3), but they could be classified as low plastic clays. The mineralogical analyses are reasonably consistent with plasticity data. Indeed, the Atterberg limits increase with the amount of phyllosilicates present in the sample, which is dependent on the amount of expandable clay minerals such as smectite or vermiculite. The absence (for TM clay) or the lack of interstratified I/Sm tends to decrease the liquid limit and the plasticity index. These values of plasticity are suitable and encouraging for optimal behaviour in pressing (cohesion) and drying (negligible contraction) which are in agreement with the range defined in the literature for ceramic production [29].

\subsection{Defects in ceramics}

\subsubsection{Lamination/Exfoliation}

This defect affects the green body and it is due to the lower pressure $\left(<150 \mathrm{~kg} / \mathrm{cm}^{2}\right)$ and a larger finer fraction. Industrial tests show that use of the mixtures pressed with lower pressure provokes a higher intergranular space of the pressed bodies and cannot be evacuated by the air between particles. This defect can be eliminated by increasing pressure to $250 \mathrm{~kg} / \mathrm{cm}^{2}$ according to the Ceramic International Standard (ISO).

\subsubsection{Cracks}

The apparition of the visible or invisible cracks in the dried earthenware tiles is the result of the fast drying (the drying cycle $<10 \mathrm{~min}$ ). The hot air cannot propagate in all parts of the pieces with even intensity. Parts exposed to the flux, will be quickly dried, whereas the inside of the piece undergoes a drying shrinkage with a delay while compared to the exposed parts. The result is the creation of the warping or deformation followed by the cracks. During firing, the use of the mixtures with large finer fraction (the proportion of $<2 \mu \mathrm{m}$ fraction is $\sim 60 \%$ ) disrupts the gases clearing, which is in agreement with the literature [30] [31]. In fact, in the preheating zone of the furnance, there are chemical reactions and physical transformations that take place such as expulsion of the adsorbed water $\left(\sim 180^{\circ} \mathrm{C}\right)$, dehydroxylation $\left(400^{\circ} \mathrm{C}-600^{\circ} \mathrm{C}\right)$, and quartz transformation (at $\left.573^{\circ} \mathrm{C}\right)$. If firing treat- 
Table 3. The parameters of plasticity of studied clays.

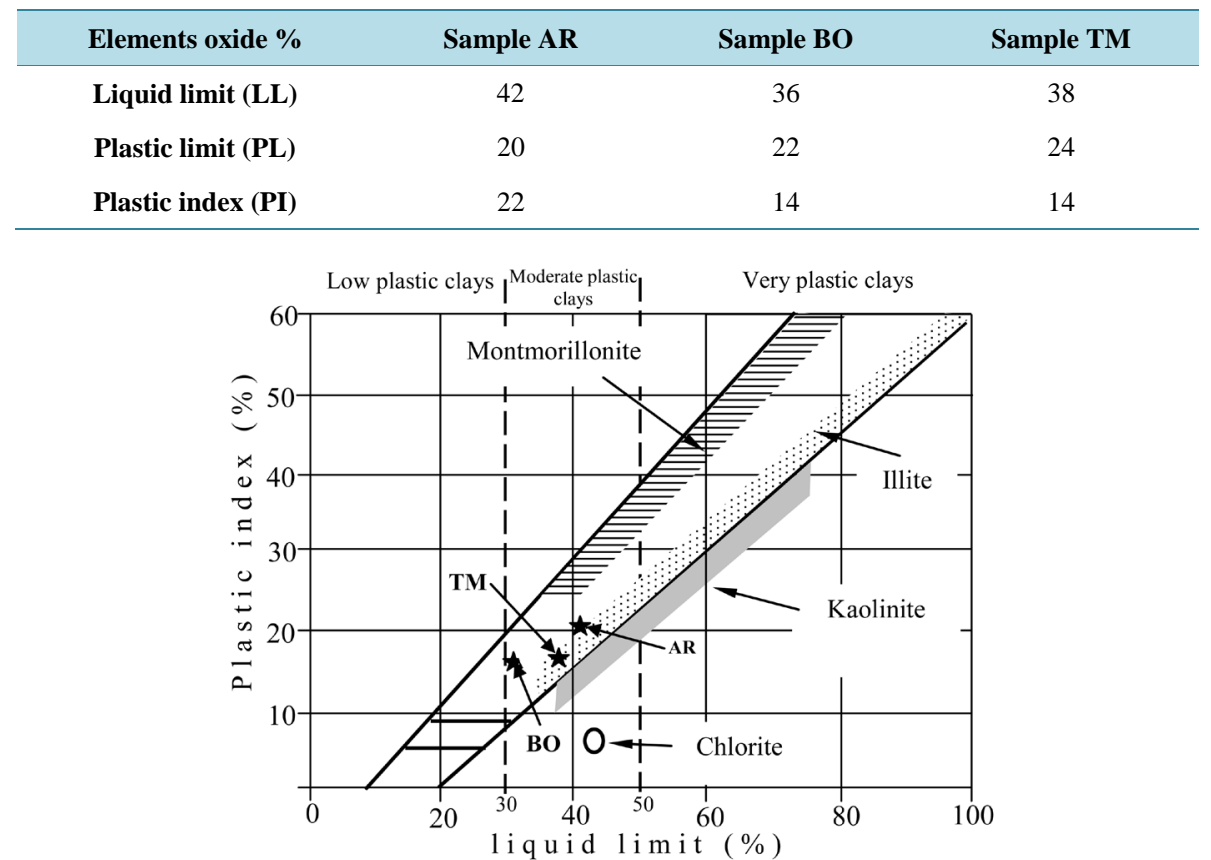

Figure 3. Situation of the studied clays on the Holtz and Kovacs [28] diagram.

ments were conducted very fast (when the temperature of a roller furnance is $1100^{\circ} \mathrm{C}$ and the cycle is $<30$ min), it can provoke the cracks.

To avoid this defect, it is necessary 1 ) to add a grease-remover; $15 \%$ - 20\% (sands, crushed glass, grogs, feldspars, pegmatite, and chamotte; the latter is made up of brick debris and biscuit waste) to reduce the plasticity and the linear shrinkage, to ameliorate water absorption, which makes the clays easy to dry and to facilitate the gas clearing, 2) to increase the drying cycle; $20 \mathrm{~min}$, 3) to assure a progressive and slow or moderate cycle of heating; $40 \mathrm{~min}$.

\subsubsection{Lower Mechanical and Flexural Strength}

During the pressing process, the increase of pressure of green bodies provokes the reduction of intergranular space and shows a solid-state sintering [32]. However, industrial tests show that the lower mechanical and flexural strength come from mixtures containing more than $30 \%$ of the grease-remover or the ceramic tiles are dried and fired at lower temperature and cycle. The solutions are assured by 1) increasing the firing cycle of $60 \mathrm{~min}$ at $1100^{\circ} \mathrm{C}$; 2) adjusting the water content in mixtures at $6.5 \%-7.5 \%$ and; 3) increasing pressure to $250 \mathrm{~kg} / \mathrm{cm}^{2}$ according to the Ceramic International Standard (ISO).

\subsubsection{Craters with Black Grains}

The defect is provoked by iron oxide. Indeed, the decomposition of organic matter produces a carbone deposit in the midst of ceramic bodies. The last reacts with hematite $\left(\mathrm{Fe}_{2} \mathrm{O}_{3}\right)$ according to reaction $\mathrm{C}+\mathrm{Fe}_{2} \mathrm{O}_{3} \rightarrow \mathrm{CO}+$ $2 \mathrm{FeO}$. The defect is also created by pyrite when wasn't sufficiently crushed. The soufre is liberated at the form of sulfuric gas and the rest of the Fe-oxide melt and give black grains in the craters. As reported in literature [33] [34], when pyrite is pyrolyzed at temperatures above $600 \mathrm{~K}$, it is decomposed according to the following equation: $\mathrm{FeS}_{2} \rightarrow \mathrm{FeS}+\mathrm{S}$. The produced sulfur can react with the hydrogen to form $\mathrm{H}_{2} \mathrm{~S}: \mathrm{S}+\mathrm{H} \rightarrow \mathrm{H}_{2} \mathrm{~S}$.

This defect can be tackled by reducing the powder grain size. It can be eliminated by increasing the firing cycle.

\subsubsection{Craters with White Grains}

The defect is attributed to the presence of debris of calcareous or gypsum badly crushed. Indeed the calcareous 
transforms to lime [35], when the lime absorbs water, it increases in volume and bursts the ceramic bodies; $\mathrm{CaO}$ $+\mathrm{H}_{2} \mathrm{O} \rightarrow \mathrm{Ca}(\mathrm{OH})_{2}$. The gypsum decreases in volume at the firing process. In the humid atmosphere, the gypsum increases in volume and it bursts also the ceramic bodies. It can be noticed that the craters provoked by gypsum are less important than those resulted by debris of calcareous. In the two cases, the problem can be solved by crushing and scattering the finer particles in the midst of ceramic bodies.

\subsubsection{Chip}

They are breaks in the corners of ceramic bodies. These are the result of insufficient filling of the paste in the molds. There is an excess of material in the middle of the square than in the edges. Moreover, during firing process, the dimensional variations are heterogeneous, which provokes deformation and chip.

\section{Conclusions}

The studied clays, collected from different locations in Tunisia indicate a predominance of illite and kaolinite, with a small quantity of illite/smectite mixed-layer and chlorite. The non-clay minerals are quartz, calcite, feldspar, gypsum, and dolomite. Chemical analyses show that these clays are rich in $\mathrm{Si}$, $\mathrm{Al}$, and $\mathrm{K}$ with minor contents of Mg, Ti, and Mn, accompanied by a significant number of iron oxides. Raw materials show little to moderate plasticity. The results are favourable for uses in ceramic.

Lamination, cracks and lower mechanical and bending strength are the main defects in Tunisian products of ceramic products. Lamination defect can be eliminated by increasing pressure to $250 \mathrm{~kg} / \mathrm{cm}^{2}$ according to the Ceramic International Standard (ISO); cracks defect can be avoided by adding a grease-remover (15\% - 20\%) and increasing the drying cycle ( $20 \mathrm{~min})$. Craters defect can be tackled by reducing the powder grain size and by increasing the firing cycle (40 min).

\section{References}

[1] Bouaziz, S., Jedoui, Y., Barrier, E. and Angelier, J. (2003) Neotectonics in the Tyrrhenian Marine Deposits of the Southeastern Tunisian Coast: Implications for Sea Level Changes. Comptes Rendus Geosciences, 335, 247-254. http://dx.doi.org/10.1016/S1631-0713(03)00031-2

[2] Ben Ferjani, A., Burollet, P.F. and Mejri, F. (2006) Petroleum Geology of Tunisia. Mémoires Entreprise Tunisienne des Activités pétrolières (A Renewed Synthesis), 22, $230 \mathrm{p}$.

[3] Baccour, H., Medhioub, M., Jamoussi, F., Mhiri, T. and Daoud, A. (2008) Mineralogical Evaluation and Industrial Applications of the Triassic Clay Deposits, Southern Tunisia. Materials Characterization, 59, 1613-1622. http://dx.doi.org/10.1016/j.matchar.2008.02.008

[4] Baccour, H., Medhioub, M., Jamoussi, F. and Mhiri, T. (2009) Influence of Firing Temperature on the Ceramic Properties of Triassic Clays from Tunisia. Journal of Materials Processing Technology, 209, 2812-2817. http://dx.doi.org/10.1016/j.jmatprotec.2008.06.055

[5] Mahmoudi, S., Srasra, E. and Zargouni, F. (2008) The Use of Tunisian Barremian Clay in the Traditional Ceramic Industry: Optimization of Ceramic Properties. Applied Clay Science, 42, 125-129. http://dx.doi.org/10.1016/j.clay.2007.12.008

[6] Mahmoudi, S., Srasra, E. and Zargouni, F. (2010) Firing Behaviour of the Lower Cretaceous Clays of Tunisia. Journal of African Earth Sciences, 58, 235-241. http://dx.doi.org/10.1016/j.jafrearsci.2010.03.004

[7] Moussa, L., Srasra, E. and Bouzouita, K. (1992) Stabilisation of Clay Suspension Used in Tunisian Ceramics. Miner Petrography Acta, XXXV-A, 147-159.

[8] Ben M'Barek, M., Srasra, E. and Zargouni, F. (2002) Characterization of Paleocene Clays in the North West of Tunisia and Their Use in the Field of Ceramics. Africa Geosciences Reviews, 9, 107-117. (In French)

[9] L.C.P.C. (1987) Atterberg Limits, Liquid Limit, Plasticity Limit. Publication of L.C.P.C., Vol. 26, 10-15. (In French)

[10] Jeridi, K., Hachani, M., Hajjaji, W., Moussi, B., Medhioub, M., Lopez-Galindo, A., Kooli, F., Zagouni, F., Labrincha, J.A. and Jamoussi, F. (2008) Technological Behaviour of Some Tunisian Clays Prepared by Dry Ceramic Processing. Clay Minerals, 43, 339-350. http://dx.doi.org/10.1180/claymin.2008.043.3.01

[11] Höllerl, N. (1993) The Return of the Dry Grinding Process. Ceramic World Review, 8, 82-88.

[12] Proust, C., Jullien, A. and Forestier, L. (2004) Determination of Atterberg Limits by Dynamic Gravimetry. Comptes Rendus Geoscience, 336, 1233-1238. (In French) http://dx.doi.org/10.1016/j.crte.2004.06.003

[13] Ancey, C. (2007) Plasticity and Geophysical Flows: A Review. Journal of Non-Newtonian Fluid Mechanics, 142, 4-35. http://dx.doi.org/10.1016/j.jnnfm.2006.05.005 
[14] Yu, H.S., Khong, C. and Wang, J. (2007) A Unified Plasticity Model for Cyclic Behaviour of Clay and Sand. Mechanics Research Communications, 34, 97-114. http://dx.doi.org/10.1016/j.mechrescom.2006.06.010

[15] Modesto, C. and Bernardin, A.M. (2008) Determination of Clay Plasticity: Indentation Method versus Pfefferkorn Method. Applied Clay Science, 40, 15-19. http://dx.doi.org/10.1016/j.clay.2007.06.007

[16] Grim, R.E., Bray, R.H. and Bradley, W.F. (1937) The Mica in Argillaceous Sediments. American Mineralogist, 22, 813-829.

[17] Gallala, W., Gaied, M.E. and Montacer, M. (2009) Detrital Mode, Mineralogy and Geochemistry of the Sidi Aïch Formation (Early Cretaceous) in Central and Southwestern Tunisia: Implications for Provenance, Tectonic Setting and Paleoenvironment. Journal of African Earth Sciences, 53, 159-170. http://dx.doi.org/10.1016/j.jafrearsci.2009.01.002

[18] Carretero, M.I., Dondi, M., Fabbri, B. and Raimondo, M. (2002) The Influence of Shaping and Firing Technology on Ceramic Properties of Calcareous and Non-Calcareous Illitic-Chloritic Clays. Applied Clay Science, 20, 301-306. http://dx.doi.org/10.1016/S0169-1317(01)00076-X

[19] Ferrari, S. and Gualteri, A.F. (2006) The Use of Illitic Clays in the Production Stoneware Tile Ceramics. Applied Clay Science, 32, 73-81. http://dx.doi.org/10.1016/j.clay.2005.10.001

[20] Sedmale, G., Sperberga, I., Sedmalis, U. and Valancius, Z. (2006) Formation of High-Temperature Crystalline Phases in Ceramic from Illite Clay and Dolomite. Journal of the European Ceramic Society, 26, 3351-3355. http://dx.doi.org/10.1016/j.jeurceramsoc.2005.10.012

[21] Wattanasiriwech, D., Srijan, K. and Wattanasiriwech, S. (2009) Vitrification of Illitic Clay from Malaysia. Applied Clay Science, 43, 57-62. http://dx.doi.org/10.1016/j.clay.2008.07.018

[22] Bain, A.J. (1987) Composition and Properties of Clay Used in Various Fields of Ceramics. Part II. Ceramic Forum International, 63, 44-84.

[23] Klaarenbeek, F.W. (1961) The Development of Yellow Colours in Calcareous Bricks. Transactions of the British Ceramic Society, 60, 739-771.

[24] Kreimeyer, R. (1987) Some Notes on the Firing Colour of Clay Bricks. Applied Clay Science, 2, 175-183. http://dx.doi.org/10.1016/0169-1317(87)90007-X

[25] Dondi, M. (1999) Clay Materials for Ceramic Tiles from the Sassuolo District (Northern Apennines, Italy), Geology, Composition and Technological Properties. Applied Clay Science, 15, 337-366. http://dx.doi.org/10.1016/S0169-1317(99)00027-7

[26] Jordán, M.M., Sanfeliu, T. and De la Fuente, C. (2001) Firing Transformations of Tertiary Clays Used in the Manufacturing of Ceramic Tiles Bodies. Applied Clay Science, 20, 87-95. http://dx.doi.org/10.1016/S0169-1317(00)00044-2

[27] Sousa, S.J.G. and Holanda, J.N.F. (2005) Development of Red Wall Tiles by the Dry Process Using Brazilian Raw Materials. Ceramics International, 31, 215-222. http://dx.doi.org/10.1016/j.ceramint.2004.05.003

[28] Alcântara, A.C.S., Beltrão, M.S.S., Oliveira, H.A., Gimenez, I.F. and Barreto, L.S. (2008) Characterization of Ceramic Tiles Prepared from Two Clays from Sergipe-Brazil. Applied Clay Science, 39, 160-165. http://dx.doi.org/10.1016/j.clay.2007.05.004

[29] Holtz, X. and Kovacs, X. (1981) The Relationship between Geology and Landslide Hazards of Atchison, Kansas and Vicinity. Kansas Geotechnical Survey. Current Research in Earth Science, 3, 244.

[30] Van der Merwe, D.H. (1964) Prediction of Heave from the Plasticity Index and Percentage of Clay Fraction of Soils. Transactions of the South African Institution of Civil Engineers, 6, 103-107.

[31] Negre, F., Sánchez, E., García, J., Sanz, V. and Jarque, J.C. (1998) Evaluating Lamination in Porcelain Tile-I: Measurement. American Ceramic Society Bulletin, 77, 63-68.

[32] Romagnoli, M., Burani, M., Tari, G. and Ferreira, J.M.F. (2007) A Non-Destructive Method to Assess Delamination of Ceramic Tiles. Journal of the European Ceramic Society, 27, 1631-1636. http://dx.doi.org/10.1016/j.jeurceramsoc.2006.05.069

[33] González-García, F., Romero-Acosta, V., Garcia-Ramos, G. and González-Rodriguez, M. (1990) Firing Transformations of Mixtures of Clays Containing Illite, Kaolinite and Calcium Carbonate Used by Ornamental Tile Industries. Applied Clay Science, 5, 361-375. http://dx.doi.org/10.1016/0169-1317(90)90031-J

[34] Bommannavar, A.S. and Montano, P.A. (1982) Mössbauer Study of the Thermal Decomposition of FeS 2 in Coal. Fuel, 61, 523-528. http://dx.doi.org/10.1016/0016-2361(82)90174-0

[35] Montano, P.A. and Vaishnava, P.P. (1982) In Situ ${ }^{57}$ Fe Mössbauer Study of the Thermodynamics and the Reaction Kinetics of $\mathrm{FeS}_{2}$. Proceedings of Indian Science Academy, Jaipur, India, 9, 281-283.

[36] Assal, H.H., El-Didamony, H., Ramez, M. and Mossalamy, F.H. (1999) The Role of Lime Inclusions on the Properties of Fired Clay Articles. Industrial Ceramics, 19, 82-92. 
Scientific Research Publishing (SCIRP) is one of the largest Open Access journal publishers. It is currently publishing more than 200 open access, online, peer-reviewed journals covering a wide range of academic disciplines. SCIRP serves the worldwide academic communities and contributes to the progress and application of science with its publication.

Other selected journals from SCIRP are listed as below. Submit your manuscript to us via either submit@scirp.org or Online Submission Portal.
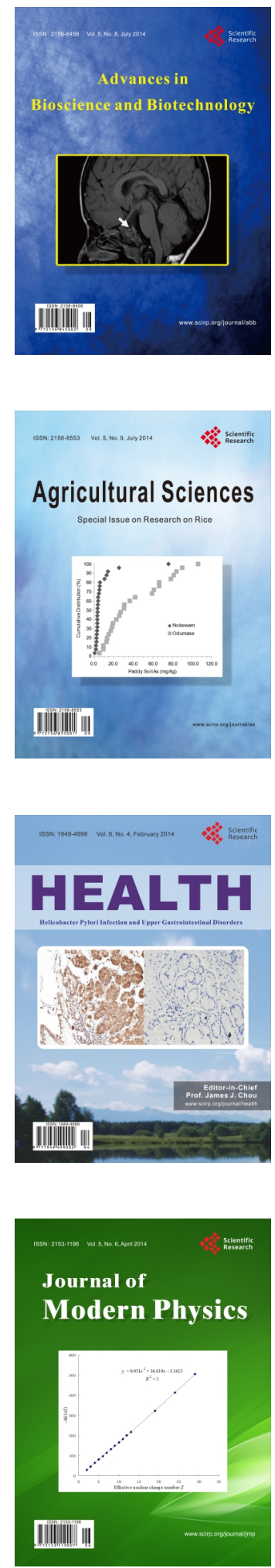
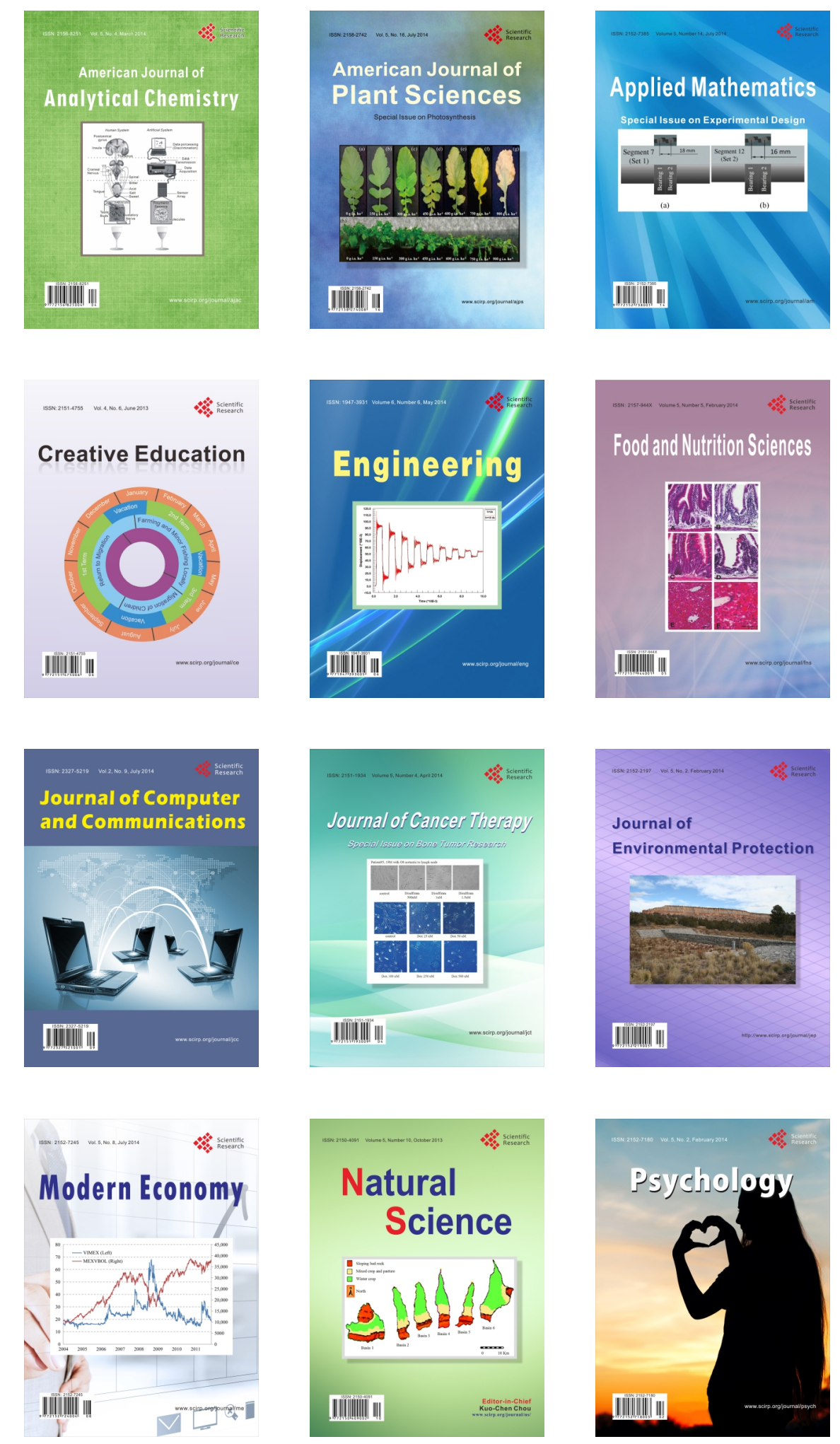